IRSTI 10.16.02.

UDC 369.032.2

https://doi.org/10.46914/1562-2959-2020-1-4-208-213

Y.S. BAIMAKHANOV, ${ }^{1}$

PhD student.

A.T. BEKNAZAROVA, ${ }^{2}$

c.e.s., associate professor.

D.M. DADABAYEVA, ${ }^{2}$

c.e.s.

Al-Farabi Kazakh National University. ${ }^{1}$

Turan University ${ }^{2}$

\title{
THEORETICAL FOUNDATIONS OF PUBLIC ADMINISTRATION IN THE CONTEXT OF INCREASING THE EFFICIENCY OF LOCAL SELF-GOVERNMENT
}

\begin{abstract}
The analysis of the efficiency of public administration is one of the most pressing problems, both in theory and in practice. For the further development of a socially oriented state in Kazakhstan, it becomes increasingly important to study theoretical and methodological problems of determining the efficiency of local authorities. The practical significance of the research carried out by the authors lies in the fact that the theoretical provisions, methodological approaches and practical conclusions developed and reasoned in it make it possible to determine the prospects for the development of the system of interbudgetary relations both at the republican and regional levels of government, to substantiate the directions of implementation of the tasks set in this connection, contribute to positive socioeconomic transformations taking place in the regions of Kazakhstan. The study of the problems of the formation of interbudgetary relations is also in the center of attention of economic science. In this regard, the authors in the article define the tasks of increasing the efficiency of the work of local authorities and reforming the system of interbudgetary relations. The subject of the research is the interaction of public authorities and representatives of local self-government in the modernization of inter-budgetary relations to ensure the socio-economic development of the region, increase the level of economic efficiency of local authorities. Evaluations of the efficiency of public authorities are becoming an important tool in innovative management technologies.
\end{abstract}

Key words: public administration, efficiency assessments, inter-budget regulation, management technologies, methodological approaches, local self-government.

In the first Message of the Head of State Kassym-Jomart Tokayev to the people of Kazakhstan "Constructive public dialogue is the basis of stability and prosperity in Kazakhstan" it is indicated that one of the key areas that give impetus to economic growth in the context of modernization of the Republic of Kazakhstan is the transformation of the budgetary process in order to create favorable conditions for sustainable development of the national economy of the country and its regions, which, in turn, will contribute to strengthening their competitive positions. In this regard, tasks have been identified to improve the efficiency of local authorities and reform the system of interbudgetary relations. Problems were identified: the current system of interbudgetary relations does not stimulate akimats of all levels to create their own development base - small and medium-sized businesses; regions are weakly motivated to search for additional sources of income.Therefore, the modernization of the system of interbudgetary relations determines the need and expediency of transforming a number of fundamental principles for the formation and implementation of the financial policy of the state, functionally focused on providing conditions for the expanded reproductive development of regional economies. This complex process includes, first of all, the conceptual construction of theoretical and methodological principles and algorithmically verified schemes for the implementation of the modernization of interbudgetary relations.

In the XVI-XVII centuries. the ideas of T. Hobbes and J. Locke played a certain role in the birth of the modern theory of finance. They considered the possibilities and fairness of taxation systems as a source of formation of state revenues.Financial science received an additional impetus for its further 
development in the works of A. Smith, who in his famous "Research on the Nature and Causes of the Wealth of Nations", along with other issues, paid attention to the problem of the distribution of financial resources and powers between the levels of government.

German researcher K. Eeberg in his work "Essays on Financial Science" notes that in accordance with the financial principles "the state, region, community must obtain and spend the material benefits necessary to achieve their goals." In our opinion, this approach allows us to consider the budgets of various levels of the budget system as independent and subject to uniform organizational principles. A certain role in the development of the theory of local finance and interbudgetary regulation was played by the research of the French researcher G. Jez, who studied the nature of the budget both from the standpoint of financial theory and from the standpoint of law [1].

Back in the early twentieth century, W.F. Willoughby noted three main directions implementation of budget reforms: first, how will budgets contribute to ensure public control; second, how budgets will enhance cooperation between the legislative and executive branches of government, and third, how budgets will ensure administrative and managerial productivity. It should be noted that in economics historically more attention has been paid to the problems of the formation of state revenues, while less attention has been paid to the efficiency and expediency of spending funds. The situation changed in the twentieth century, when, with the advent of the teachings of J.M. Keynes, the attitude towards the state budget changed, which began to be considered as the most important instrument of state regulation of the economy.

In A. Pigou's theory of public welfare, the budget is viewed as an effective mechanism for redistributing income to increase aggregate welfare, on the basis of which, in our opinion, one can draw conclusions about the functions of inter-budgetary regulation as a tool that allows to achieve similar goals in an optimal way [2].

It should be noted that the evolution of the financial system of the state and interbudgetary relations is directly related to the development of the state structure, in particular with the establishment of institutionalization of relations between public authorities and local governments in various forms. To determine the place and role of interbudgetary regulation, it is necessary to consider the foundations of the theory and practice of the formation and development of interbudgetary relations. The founder of the theory of federalism is considered to be I. Altusius, who developed the "federal theory of popular sovereignty." The development of the theory of federalism was carried out by prominent US statesmen A. Hamilton, D. Madison, D. Jay.It should be noted that federalism as a fundamental principle of state structure and, in particular, "budget federalism" as one of its aspects has a significant impact on the organization and development of systems of budgetary relationships and interbudgetary regulation.

A great contribution to the development of the theory of budgetary federalism was made by W. Oates, who developed in the early 70s. the last century, the "theorem on decentralization", according to which, in the absence of cost savings from the centralized provision of public goods, the level of social welfare will be higher if effective levels of consumption are provided in each territorial entity than if any single, unified level of consumption would be maintained for all territorial entities.

World and domestic experience in the development of regional systems of interbudgetary regulation shows that the formation of interbudgetary relations at the local level is closely related to the general foundations of budgetary formation and the relationship between republican and local authorities. In Kazakhstan, studies in the field of budgetary management were carried out by U.B. Baymuratov, K.K. Ilyasov, U.M. Iskakov, K.Zh. Bertaeva, B.Zh. Ermekbaeva. However, their main focus was on the study of the state budget, as well as the possibility of optimizing the budget process. To form the theory of interbudgetary relations, it was necessary to develop the financial system and finance as distributional relations, which would actualize the issues of interbudgetary regulation [3].

In the works of Kazakh scientists U.B. Baimuratov, K.K. Ilyasov. Under the formation and development of the economy in the Republic of Kazakhstan, it was supposed to revise a number of provisions of financial and economic theory, budget process and practice of inter-budgetary relations. The systems of financial and budgetary relations, changes in the role of the budgetary system in the reproduction process have been investigated. Scientists note the increasing role of the budget system in state regulation of the economy and the activation of the financial and budgetary mechanism, as 
well as decisions in the field of financial and budgetary and tax policy, budget regulation, financial independence and strengthening the revenue base of the budgets of local governments.In practice, there are various forms of regulation of interbudgetary relations, which are determined taking into account the tax potential of each of the budget levels, the results of assessing the objective needs of the regions, approved natural norms. According to the Budgetary Code of the Republic of Kazakhstan, the forms of regulation of inter-budgetary relations are established in accordance with the medium-term fiscal policy [4].

The financial independence of the region is closely related to the presence on its territory of the necessary economic and financial potential, which makes it possible to form the local budget using revenues collected on its territory.In the absence of this necessary financial base in the region, it becomes necessary to redistribute centralized funds of the state budget, mainly the Republican budget, between local budgets of different levels.

In essence, the system of interbudgetary relations is one of the main mechanisms through which the interaction of the subjects of management takes place, namely the interaction between the hierarchical levels of power - the republican and regional, regional and district.This system is a set of principles, methods, methods and financial instruments used in the formation of revenues and expenditures of budgets of different levels, through which the state establishes budgetary relationships, directions of budget flows and allocates centralized resources.

Thus, summarizing the above, it can be determined that the essence of interbudgetary relations lies in the economic and legal vertical and horizontal interaction of public law entities represented by their authorized bodies regarding the formation, distribution, redistribution and regulation of budgetary powers and sources of their funding to maximize the provision of the population. territory with budgetary resources.

The need for such regulation arises mainly when the authorities of a lower territorial level, when forming budgets, for objective reasons, do not have enough funds from income sources fixed on a permanent basis in whole or in part (at divided tax rates or in percentages) to ensure a minimum necessary expenses in accordance with the functions and powers assigned to them.

Interbudgetary regulation is carried out, as a rule, by the authorities of a higher level by means of vertical (between different links of the budget system) and horizontal (in the context of budgets of the same link of the budget system) equalization of the budgetary provision of territorial entities, in which it is below the minimum required level.The term interbudgetary regulation can have a broad interpretation, taking into account the regulatory impact through the budgetary system on the economic and social processes in the country.

Horizontal equalization in some countries (for example, in Germany) also takes place in the order of centralized withdrawal (through the corresponding settlement (clearing) center under the German Ministry of Finance, bypassing the federal budget) on a progressive scale in the form of negative transfers of funds from budgets where such security is above average level, in favor of budgets, where it is less than this level [5].

Interbudgetary regulation is not limited to equalizing the budgetary provision of territorial entities, where it is less than the minimum required level. Its functions also include reimbursement to budgets of additional expenses or revenue losses caused by decisions taken by the authorities of another level, and the possible share participation of higher-level budgets in the expenditures of lower-level budgets, meaning the stimulation of priority (most socially significant) areas from the position of higher-level authorities. spending of these budgets.

In most countries, interbudgetary regulation is carried out by transferring funds in various forms directly from the budget of the higher level to the corresponding lower budgets.In some countries (for example, Austria, Germany, India, Russia), joint (general) taxes are also used for this purpose, when some of them are distributed on a temporary basis (with a deadline of at least the next financial year) between different levels of the budget system.

Interbudgetary relations can be directly between the budgets of the same level. For example, to pool financial resources in order to solve problems of mutual interest. In the Republic of Kazakhstan, 
they have not yet received widespread use. In rare cases, financial assistance is provided from lower-level budgets to higher-level budgets. Foreign experience does not allow finding a standard that is completely suitable for Kazakhstan. Each country, along with common approaches, has its own characteristics of the mechanism of interbudgetary relations. For example, in many countries, in particular in the United States, taxes are delineated between the levels of the budget system on the principle of "one tax - one budget." At the same time, in Canada, Austria, Germany, India, along with separate taxes, each of which is sent only to the budget of one level or another, joint taxes are also applied.

They, being "large" taxes with a widespread tax base throughout the country, to one degree or another participate in the formation of budgets of different levels both on a permanent basis (Canada) and in combination with taxes distributed on a temporary basis.

In most countries, regional and local authorities have some rights in the field of taxation in order to, to one degree or another, independently solve the problem of budget deficit-freeness or reducing their deficit, before relying on financial assistance in various forms from the budget of a higher territorial level. The study of the functions of interbudgetary relations as an element of the financial system and interbudgetary regulation as an element of budgetary policy are devoted to the work of a number of Kazakhstani and foreign scientists [6].

Despite the differences in the understanding of the essence of interbudgetary relations and interbudgetary regulation, their inherent basic functions coincide. In the works of Russian scientists, the functions of interbudgetary relations are usually considered. However, within the framework of this study, the functions of interbudgetary regulation, which is one of the elements of budgetary policy, play a greater role, while interbudgetary relations are an integral part of the state budget system. Therefore, when organizing financial management, it is necessary to consider and optimize the implementation of the functions of inter-budgetary regulation. Note that the functions inherent in interbudgetary relations and interbudgetary regulation are similar: they traditionally single out equalizing and stimulating functions that are manifested both at the republican and regional levels.

The nature and degree of their manifestation depend on the model of interbudgetary relations, predetermined by the peculiarities of the state structure and a number of other factors.

Analyzing the implementation of the functions of interbudgetary regulation in the current economic situation in the country, the following conclusions can be drawn:

- the equalizing function of interbudgetary regulation, of course, is being updated in connection with a decrease - and different in degree - in revenues of local budgets. This raises the problem of changing the relevant conditions - the "rules of the game", which can mean a transition to soft budget constraints, and therefore provoke ineffective behavior of recipients of equalizing interbudgetary transfers;

- the implementation of the supporting function of interbudgetary regulation in conditions of a budget deficit at all levels of the budgetary system can lead to untimely and / or incomplete financing of delegated powers, and, consequently, to their poor performance by the recipient of interbudgetary transfers.

In foreign practice, systems of general transfers, or universal, equalizing, and a system of targeted, or special. The general transfer system is used to equalize horizontal budget differences in order to match the tax potential (tax revenue) and the financing needs of the required expenditures. In exceptional cases, with the help of the system of general transfers, the issues of assistance to "problem" territories are solved.

Transfers between budget levels are subdivided into general transfers, targeted current transfers, and targeted development transfers. This feature allows you to assign them the status of funds of targeted funds. The amounts of targeted transfers and budget loans used not for their intended purpose in accordance with the act of the state financial control body are subject to mandatory return to the higher budget that allocated these transfers and loans within a month after the signing of the control act in the appropriate manner. 
To assess the effectiveness of interbudgetary regulation, it seems appropriate to highlight the main factors affecting its organization and implementation in the region. Some of them are due to the peculiarities of the implementation of budgetary policy, while others are associated with the impact of the external environment. The effectiveness of inter-budgetary regulation at the regional level can be analyzed according to various schemes.

\section{LIST OF LITERATURE}

1 About measures on further improvement of state administration system of the Republic of Kazakhstan / the presidential Decree. No. 806. - Astana, Akorda, December 26, 2018.

2 Afanasiev K.S., Kazennov A.S., Popov M.V. State regulation of the economy as a means of economic policy: monograph. Publishing House of Leningrad University Publishing House of Leningrad State University A.S. Pushkin. - M., 2017. 148 p.

3 Brimbetova N.Zh. Methodological approaches to evaluation of social development of regions of Kazakhstan // News of the national academy of sciences of the Republic of Kazakhstan. 2016. Volume 3. Number 307. P. 53-57.

4 Zhangirova R.N. Development of public-private partnership in the Republic of Kazakhstan // Bulletin Of KazNPU. 2014. No. 5. P. 20-27.

5 Abdelhalim Boussabaine Risk Pricing Strategies for Public-Private Partnership Projects (Innovation in the Built Environment). 1st Edition. - Wiley-Blackwell, 2013. 278 p.

6 Eduardo Engel, Ronald D. Fischer Alexander Galetovic The Economics of Public-Private Partnerships: A Basic Guide. - Cambridge University Press, 2014. 192 p.

Е.С. БАЙМАХАНОВ, ${ }^{1}$ докторант.

А.Т. БЕКНАЗАРОВА, ${ }^{2}$

э.Ғ.К., доцент.

Д.М. ДАДАБАЕВА, ${ }^{2}$

Э.Ғ.К.

Әл-Фараби атындағы

Қазақ ұлттық университеті. ${ }^{1}$

«Тұран» университеті

\section{ЖЕРГІЛІКТІ ӨЗІН-ӨЗІ БАСКАРУДЫН ТИІМДІЛІГІН \\ АРТТЫРУ МӘНМӘТІНІНДЕГІ МЕМЛЕКЕТТІК \\ БАСҚАРУДЫН ТЕОРИЯЛЫҚ НЕГІЗДЕРІ}

\section{Андатпа}

Мемлекеттік басқару тиімділігін талдау - теориялық тұрғыдан да, практикалық тұрғыдан да өзекті мәселелердің бірі. Қазақстанда әлеуметтік бағдарланған мемлекеттің одан әрі дамуы үшін жергілікті билік органдарының тиімділігін анықтаудың теориялық және әдістемелік мәселелерін зерттеу маңызды болып отыр. Авторлар жүргізген зерттеудің практикалық маңыздылығы онда әзірленген және негізделген теориялық ережелер, әдіснамалық тәсілдер мен практикалық тұжырымдар бюджетаралық қатынастар жүйесін басқарудың республикалық және аймақтық деңгейлерінде анықтауға, осыған байланысты қойылған міндеттерді іске асыру бағыттарын негіздеуге мүмкіндік береді. Қазақстанның аймақтарында болып жатқан оң әлеуметтік-экономикалық қайта құруларға ықпал етеді. Бюджетаралық қатынастарды қалыптастыру мәселелерін зерттеу экономикалық ғылымның да назарында. Осыған байланысты мақалада авторлар жергілікті билік органдарының тиімділігін арттыру және бюджетаралық қатынастар жүйесін реформалау бойынша міндеттерді айқындады. Зерттеудің тақырыбы - облыстың әлеуметтік-экономикалық дамуын қамтамасыз ету, жергілікті билік органдарының экономикалық тиімділігі деңгейін арттыру үшін бюджетаралық қатынастарды модернизациялаудағы мемлекеттік органдар мен жергілікті органдардың өзара әрекеті. Мемлекеттік органдар қызметінің тиімділігін бағалау инновациялық басқару технологиясының маңызды құралына айналуда.

Тірек сөздер: мемлекеттік басқару, тиімділігін бағалау, басқару технологиялары, әдіснамалық тәсілдер, жергілікті өзін-өзі басқару. 
Е.С. БАЙМАХАНОВ, ${ }^{1}$

докторант.

А.Т. БЕКНАЗАРОВА, ${ }^{2}$

к.э.Н., доцент.

Д.М. ДАДАБАЕВА, ${ }^{2}$

К.Э.Н.

Казахский национальный университет им. аль-Фараби. ${ }^{1}$

Университет «Туран» ${ }^{2}$

\title{
ТЕОРЕТИЧЕСКИЕ ОСНОВЫ ГОСУДАРСТВЕННОГО УПРАВЛЕНИЯ В КОНТЕКСТЕ ПОВЫШЕНИЯ ЭФФЕКТИВНОСТИ МЕСТНОГО САМОУПРАВЛЕНИЯ
}

\begin{abstract}
Аннотация
Анализ эффективности государственного управления является одной из самых актуальных проблем как в теории, так и на практике. Для дальнейшего развития социально ориентированного государства в Казахстане все более важным становится исследование теоретико-методологических проблем определения эффективности местных органов власти. Практическая значимость выполненного авторами исследования состоит в том, что разработанные и аргументированные в нем теоретические положения, методологические подходы и практические выводы позволяют определить перспективы развития системы межбюджетных отношений как на республиканском, так и на региональном уровнях управления, обосновать направления реализации поставленных в связи с этим задач, способствуют позитивным социально-экономическим преобразованиям, происходящим в регионах Казахстана. Исследование проблем формирования межбюджетных отношений находится и в центре внимания экономической науки. В этой связи авторами в статье определены задачи по повышению эффективности работы местных органов власти и реформированию системы межбюджетных отношений. Предметом исследования выступает взаимодействие органов государственной власти и органов местного самоуправления при модернизации межбюджетных отношений для обеспечения социально-экономического развития региона, повышения уровня экономической эффективности местных органов власти. Оценки эффективности деятельности органов государственной власти становятся важным инструментом в инновационных управленческих технологиях.
\end{abstract}

Ключевые слова: государственное управление, оценки эффективности, межбюджетное регулирование, управленческие технологии, методологические подходы, местное самоуправление. 